416 s. [in Russ.]. [in Russ.]

3. Shuman V. Drahotsennыe y poludrahotsennыe kamny: Per. s nem. - M.: BMM AO, 2006. 312 s.

4. Diamond View User Manual. - Diamond Trading Company Ltd, 2008. 81 p.

5. Antoinette Matlins, Antonio C. Bonanno. Gem Identification Made Easy - Gemstone Press, Woodstock, Vermont, 2014. - 378 p.

6. Russell Shor. Synthetic Diamonds Getting Better, But so is Detection // GIA News\&Research. April 2015. https://www.gia.edu/gia-news-research/basel-gemfest-synthetic-diamonds-detection.

\title{
SUMMARY
}

Iryna O. Rudenka. Current trends in the development of scientific and technical tools for the research of jewelery with inserts of precious stones. The paper analyses innovative scientific knowledge concerning the origin of precious stones as well as their synthetic analogues and imitations. Besides, the existing technologies and modern diagnostic devices are reviewed and the results of our own research are presented.

Methods of fluorescence analysis and research under a microscope in the study of natural precious stones, including refined ones as well as their synthetic analogues and imitations is demonstrated.

Keywords: precious stone, diamond, HPHT, CVD, ruby, sapphire, refinement, synthetic stones, fluorescence, phosphorescence.

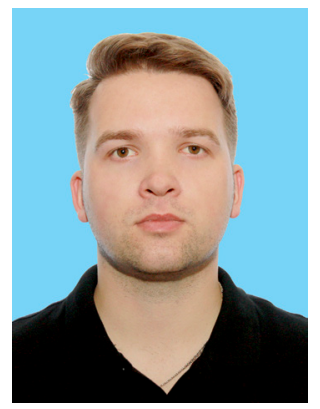

\author{
Yehor SHARAI ${ }^{\circ}$ \\ (State Research expert forensic center \\ of the Ministry of Internal Affairs of Ukraine)

\section{CONDITION OF SCIENTIFIC RESEARCH INVOLVEMENT OF EMPLOYEES OF THE EXPERT SERVICE OF THE MINISTRY OF INTERNAL AFFAIRS OF UKRAINE TO THE PRE-TRIAL INVESTIGATION}

В статті розглянуто стан наукових досліджень з питань залучення працівників Експертної служби МВС України до досудового розслідування.

Відзначено, що розширення та поглиблення наукових досліджень в галузі судово-експертної діяльності неминуче призводить до потреби використання таких досягнень і в практичній діяльності органів внутрішніх справ України.

Автором проаналізовані окремі наукові дослідження, здійснені у формі докторських, кандидатських дисертацій, монографій, низка наукових статей, навчально-методичних матеріалів, що дає підстави для висновку про те, що питання взаємодії експертів зі слідчими, оперативними працівниками, захисниками, використання ними спеціальних знань у своїй діяльності, а також залучення працівників Експертної служби МВС України до досудового розслідування в умовах сучасного змагального кримінального процесу викликають інтерес у багатьох вітчизняних і зарубіжних науковців та практиків.

Підкреслено, що потребують подальшого наукового розроблення питання криміналістичних рекоменлдацій щодо збирання та надання необхідних матеріалів з підготовки та призначення експертиз в межах міжнародної правової допомоги.

Крім того, автором констатовано, що аналіз окремих наукових досліджень, здійснених у формі докторських, кандидатських дисертацій, монографій, низки наукових статей, навчально-методичних матеріалів дає підстави для висновку про те, що питання залучення експертів Експертної служби МВС до досудового розслідування в умовах сучасного змагального кримінального процесу викликають інтеpec у багатьох вітчизняних і зарубіжних науковців і практиків. Багатогранність проблематики, широта інтересів користувачів до розвитку наукової думки й досягнень науково-технічного прогресу, важливість завдань, які виконують працівники Експертної служби МВС вказують на актуальність цієї про-

(C) Sharai Y. V., 2021

ORCID ID https://orcid.org/0000-0002-3932-3435

sharayegor@gmail.com 
блеми і дають підстави для іiі подальшого глибокого дослідження.

Ключові слова: експерт, Експертна служба МВС Украӥни, досудове розслідування, взаємодія, залучення працівників, наукові дослідження.

Problem statement. At the present stage of development for Ukraine, as well as for other countries, a serious problem is the effective fight against crime. Scholars and practitioners agree that the global system of forensic science is based on active research, scientific and methodological work and direct forensic examinations.[1]. These interrelated components are the foundation of forensic science. The expansion and deepening of scientific research in the field of forensic science inevitably leads to the need to use such achievements in the practice of internal affairs of Ukraine. Such is the need for modern crime investigation practice.

Notwithstanding the above, the full involvement of employees of the Expert Service of the Ministry of Internal Affairs of Ukraine in the pre-trial investigation and legal regulation of the Expert Service of the Ministry of Internal Affairs of Ukraine (hereinafter - the Expert Service of the Ministry of Internal Affairs) and pre-trial investigation bodies at the current stage The Ministry of Internal Affairs) has not been studied, although the issue of involving experts, in particular employees of the Expert Service of the Ministry of Internal Affairs in pre-trial investigation occupies an important place in pre-trial cooperation, as modern investigative activity is impossible without involving specialists in various fields.

Analysis of the publications that started solving this problem. Some aspects of the interaction of the subjects of pre-trial investigation at different times studied by domestic and foreign scientists: U. Alenin, A. Balashov, V.Bakhin, N. Burnashev, V. Bykov, V. Vasilinchuk, G. Vlasova, V. Veselsky, A. Gavrilov, I. Gora, I. Gutkin, L.Drapkin, A.Dudnikov, A.Ishchenko, O.Kerevich, N. Klimenko, V. Korzh, I. Krasyuk, V. Kuzmichev, V. Lysenko, S.Oslanov, V. Parkhomenko, U. Ratyshevsky, I. Sorokotyagin, D. Sorokotyagina, V. Tertyshnyk, V. Tishchenko, V.Tomin, S. Chernyavsky, A. Chichirkin, U. Chornous, O. Chuvilov, V. Shepitko, and others.

Some aspects of the interaction of expert units with units of the National Police of Ukraine at the present stage of reforming the system of the Ministry of Internal Affairs were covered in their works by experts in law and forensic science: O. Volobueva G. Gapotchenko, A. Goridko O. Kravchuk, V. Kovalev, E. Konovalov, O. Lopata, S.Olkhovenko, A.Patik, S.Perlin, O.Starchenko, U. Tsyganyuk, V. Yusupov and others. However, the issue of involving employees of the Expert Service of the Ministry of Internal Affairs in the pre-trial investigation in the context of reforming the system of the Ministry of Internal Affairs of Ukraine has not been fully explored.

Basic content. He scientific literature sources of domestic and foreign forensic and procedural research have studied the terms "interaction", "cooperation", "involvement", which combine the joint activities of two or more entities that determine the achievement of a common goal. This goal cannot be achieved without solving certain tasks set before each entity and requires the use of tools and capabilities managed by different services, departments and the number of each entity that can not achieve this goal.

In the Criminal Procedure Code of Ukraine, the term "involvement in the pre-trial investigation", as well as the term "interaction", is not disclosed, and therefore direct law does not regulate the relationship of persons with special knowledge and other pre-trial investigation bodies, do not determine the division of powers between them. in a particular investigative situation.

Elaboration of the data of forensic literature sources on topical issues of involvement of experts of the Expert Service of the Ministry of Internal Affairs in the pre-trial investigation shows that there is no single approach to understanding this activity in science either. It should be noted that the most detailed issues in the works of scientists address the problematic issues of interaction of the investigator with operational and investigative units and experts.

An important place in this process belongs to the Expert Service of the Ministry of Internal Affairs, which according to the Resolution of the Cabinet of Ministers of Ukraine № 988 of June 20, 2000 is a system of expert units, which includes: State Research Forensic Center of the Ministry of Internal Affairs of Ukraine Ministry of Internal Affairs), research forensic centers at the main departments of the Ministry of Internal Affairs in the Autonomous Republic of Crimea, Kyiv and Kyiv region, departments of the Ministry of Internal Affairs in the regions, the city of Sevastopol and transport[2].

Today, no one has any doubts about the need for in-depth research on the theory and practice of using special knowledge and involving experts in pre-trial investigation and, in particular, employees of the Expert Service of the Ministry of Internal Affairs within the scientific specialty 12.00 .09 criminal procedure and criminology; forensic examination; operational and investigative activities.

Thus, the issues of theoretical, methodological and procedural principles of forensic research in order to improve and increase their effectiveness in the investigation of crimes are devoted to doctoral and candidate dissertation research of domestic and foreign scientists:T. Averyanova "Methods of 
forensic research and trends in their development"; EB Simakova-Efremyan "Theoretical, legal and methodological principles of complex forensic research"; SF Bychkova "Modern directions of development of forensic examination in criminal proceedings"; A. Volynsky "Conceptual foundations of technical and forensic support for the detection and investigation of crimes";F. Davudov "Procedural and organizational and methodological forms of using the capabilities of science and technology to investigate and prevent crimes"; T. Tolstukhina "Modern trends in the development of forensic science based on information technology"; A. Makaryan "Integration of achievements of natural and technical sciences in criminology"; G. Prokhorov-Lukin "Theoretical and methodological foundations of forensic situation"; V. Sherstyuk "Organizational, legal and moral and psychological principles of forensic activity"; T. Sukhova "Integration of knowledge as a factor in the development of theory and practice of forensic science"; O. Volobueva "Interaction of the investigator with specialists during the collection of information about the person who committed the crime" and others.

Some problematic issues related to the use of forensic knowledge during the pre-trial investigation were considered in dissertations: S. Varenikov "Theoretical and methodological foundations of the study of the mechanism of trace formation in forensic examinations of materials, substances and products"; N. Maylis "Forensic trasology as a theory and system of solving problems in different types of examinations"; V. Lysychenko "Forensic research of documents: legal and methodological problems";E. Efremyan "Theoretical foundations and general provisions of the methodology of complex forensic soil science and trasological examination"; A. Bartsytska "Forensic technologies: the essence and place in the system of forensic science"; G. Avdeeva "Problems of forensic examination of counterfeit audiovisual products (based on criminal cases)"; M. Satevsky "Theoretical foundations of group affiliation in forensic examination"; I. Pozdeeva "Organization of interaction of the investigator with informed persons during the investigation of the destruction of construction sites";Z. Sokolovsky "The problem of using special knowledge in criminal proceedings to establish causal links of phenomena"; A. Dulova "Procedural problems of forensic examination"; K. Chaplinsky "Tactical bases of providing pre-trial investigation"; K. Sadchikova "Use of special knowledge at the stage of pre-trial investigation (procedural aspect)"; F. Javadova "Conceptual bases of development of forensic examination in modern conditions" and others.

The dissertation researches are devoted to the issue of improving the application of forensic equipment during the pre-trial investigation: G.Strelets "Genesis of the system of forensic institutions in Ukraine and directions of their activity"; V. Lysenko "Problems of forensic support for the investigation of tax crimes"; L. Palamarchuk "Forensic support for the investigation of illegal interference in the work of electronic computers (computers)"; K. Podzharenko "Forensic support for the detection and investigation of criminal infringements of intellectual property rights";I.Danovska "Forensic support of investigative activities in the internal affairs bodies" and others and monographs: I. Piroga "Theoretical and applied problems of expert support of pre-trial investigation"; V. Biryukova "Theoretical foundations of information and reference support for the investigation of crimes"; E. Lukyanchikov "Methodological principles of information support of crime investigation"; A. Ishchenko "Problems of forensic support of crime investigation";V.Biryukova "The use of computer technology to record forensic information in the investigation process"; I.Ierusalimova "Information support for the use of scientific and technical achievements in the investigation of crimes"; I.Kohutych "Forensic knowledge, their essence and the need to expand the boundaries of use";M. Budzievsky "Technical and forensic examination of documents on vehicles"; O. Bukhanchenko "Peculiarities of inspection of the place of criminal explosion with the participation of a specialist in explosives"; O. Zherebka "Forensic activity: essence, principles, organizational bases"; T. Kopylchenko "Expert errors in handwriting research and ways to overcome them"; O.Moiseeva "Expert technologies: the theory of formation and practice of application" and others.

Some issues of interaction and legal regulation of the Expert Service of the Ministry of Internal Affairs of Ukraine and pre-trial investigation units in terms of reforming the system of the Ministry of Internal Affairs of Ukraine and comments on their joint activities during investigative actions were considered in S. Perlin's works. Technical forensic support of pre-trial investigation by units of the Expert Service of the Ministry of Internal Affairs of Ukraine ";V.Kovaleva "Interaction of the investigator with employees of the expert service of the Ministry of Internal Affairs of Ukraine"; I. Efimenko "Interaction of investigative and operational units in the implementation of classified information"; U. Pilyukova "Use of information systems in expert divisions of the Ministry of Internal Affairs of Ukraine"; and other scientists.

The issues related to the defenders' use of opportunities to involve employees of expert units in the pre-trial investigation are not left out of consideration by domestic scientists in their dissertation research. In particular, it should be noted the following scientific works: E. Vybornova "Implementation of the right to protection at the stage of pre-trial investigation";I. Dubivka "Activities 
of a lawyer at the stage of pre-trial investigation"; T. Korcheva "Problems of defense counsel's activity in pre-trial proceedings and in the court of first instance"; N. Borzykh "Activities of the defender to ensure the rights and freedoms of the suspect and accused in the criminal process of Ukraine"; R. Chaika "Participation of the defense counsel in the pre-trial investigation" and others.

Some scientific interest of scientists, practitioners and other specialists in the involvement of employees of expert units in the pre-trial investigation is caused by monographic works: P. Bilenchuk, G. Strelets, O. Shulga "Expert service of Ukraine: historiography, source studies, methodology, praxeology ", which comprehensively explores the conceptual foundations of scientific and methodological and forensic support of forensic research in Ukraine: history, theory, methodology, practice;M. Shcherbakovsky "Conducting and using forensic examinations in criminal proceedings", which addresses the most pressing issues of conducting and using forensic examinations in criminal proceedings; M. Krivonos, V. Bondar "Theory and practice of using special knowledge in the investigation of crimes in the field of trafficking in narcotic drugs, psychotropic substances, their analogues or precursors"[3], in which on the basis of the results of the analysis of the international and domestic legislation, the special literature features of use of special knowledge in investigation and prevention of crimes in the field of drug trafficking, psychotropic substances, their analogues or precursors are investigated, and also offers on optimization of forensic and forensic ensuring the investigation and prevention of crimes of this category.

Considerable attention is paid to the involvement of employees of the Expert Service of the Ministry of Internal Affairs in the scientific works of: A. Ishchenko, I. Krasyuk, V. Matvienko "Problems of forensic support of crime investigation"; I.Piroga "Theoretical bases of expert activity of law-enforcement bodies"; S. Perlin "Legal and organizational features of the investigator's interaction with the units of the Expert Service of the Ministry of Internal Affairs of Ukraine"; U. Pilyukova "Some issues of interaction and regulatory regulation of the Expert Service of the Ministry of Internal Affairs of Ukraine and pre-trial investigation units of the National Police of Ukraine in terms of reforming the system of the Ministry of Internal Affairs of Ukraine"; and a number of other domestic scientists and practitioners.Recognizing the significant contribution of these and other scientists in the development of scientific and practical provisions on the interaction of bodies investigating crimes and experts, in particular, on the involvement of the Expert Service of the Ministry of Internal Affairs of Ukraine in pre-trial investigation, we note that their scientific work domestic and foreign legislation and take into account the state of law enforcement practice before the entry into force of the CPC of Ukraine in 2012.

In recent years, dissertation research has been prepared, which addressed the participation of experts in the pre-trial investigation. The works take into account the innovations of domestic procedural law, international cooperation that reflect the increasing role of experts in gathering evidence. In particular, these are candidate's dissertations: M. Romanyuk "Organizational and legal principles of expert activity in administrative proceedings"; O. Posashkova "Methods of investigating interference in the activities of a forensic expert";A.Nechval "Tactics of search in housing and other personal property"; A. Taranova "The use of special knowledge in the investigation of improper performance of professional duties by a medical or pharmaceutical worker" and others.

The issues of involving experts, including employees of the Expert Service of the Ministry of Internal Affairs of Ukraine, were discussed by domestic scientists and practitioners at conferences. In particular, the issue raised at the International Scientific and Practical Conference dedicated to the 150th anniversary of the birth of Honored Professor MS Bokarius (Kharkiv, April 18-19, 2019) deserves attentionbyProfessor $\mathrm{U}$. Chornous on conducting forensic examination in the order of international legal assistance in criminal proceedings, where the author noted that, based on the need to increase the efficiency of criminal investigation, implementation of international cooperation, processing issues related to forensic examination in the order international legal assistance, is considered important because it contributes to procedural economy, solving the problems of criminal proceedings[4].

Conclusions.The analysis of separate scientific researches carried out in the form of doctoral, candidate dissertations, monographs, a number of scientific articles. Educational and methodical materials gives grounds for the conclusion that questions of interaction of experts with investigators, operatives, defenders, their use of special knowledge in the activity. As well as the involvement of experts of the Expert Service of the Ministry of Internal Affairs in the pre-trial investigation in the context of modern adversarial criminal proceedings are of interest to many domestic and foreign scientists and practitioners. The versatility of the issue, the breadth of users' interests in the development of scientific thought and scientific and technological progress, the importance of tasks performed by employees of the Expert Service of the Ministry of Internal Affairs indicate the urgency of this problem and provide grounds for its further in-depth study. 


\section{Список використаних джерел}

1. Тмошок I., Форіс Ю. (2016). До питання про судово-експертну школу $<\mathrm{https} / / \mathrm{kndise}$.gov.ua/ news/news-view/c-do-pitanna-pro-sudovo-ekspertnu-skolu.

2. Про утворення експертної служби Міністерства внутрішніх справ : постанова Кабінету / Міністрів України від 20 червня 2000 № 988 : https://zakon.rada.gov.ua/laws/show/988-2000-п.

3. Кривонос М.В. Теорія та практика використання спеціальних знань врозслідуванні злочинів у сфері обігу наркотичних засобів,психотропних речовин, їх аналогів або прекурсорів : монографія / М. В. Кривонос, В. С. Бондар ; МВС України, Луган.держ. ун-т внутр. справ ім. Е. О. Дідоренка. Сєвєродонецьк : РВВ ЛДУВС ім. Е. О. Дідоренка. 2017. 412 с.

4. Чорноус Ю. М. Проведення судової експертизи у порядку міжнародної правової допомоги у кримінальному проваденні : Актуальні питання судової експертизи і криміналістики : збірник матеріалів міжнарод. наук.-практ. конф., присвяченої 150-річчю 3 дня народження Засл. проф. М. С. Бокаріуса (Харків, 18-19 квіт. 2019 р.). Харків : ХНДІСЕ. 508 с.

Надійшла до редакиії 11.03.2021

\section{References}

1. I. Tmoshok, Y. Foris (2016). On the question of the forensic school<https://kndise.gov.ua/news/ news-view/c-do-pitanna-pro-sudovo-ekspertnu-skolu.[in Ukr.]

2. On the formation of the expert service of the Ministry of Internal Affairs: Resolution of the Cabinet / Ministers of Ukraine of June 202000 № 988 : https://zakon.rada.gov.ua/laws/show/988-2000-п. . [in Ukr.]

3. M.Krivonos. (2017). Theory and practice of using special knowledge in the investigation of crimes in the field of drugs, psychotropic substances, their analogues or precursors: monograph / M. Krivonos, V. Bondar; Ministry of Internal Affairs of Ukraine, Luhansk State University of Internal Affairs affairs them. E. Didorenko. Severodonetsk: RVV LDUVS im. E. Didorenko, 2017. 412 p. .[in Ukr.]

4. J. Chornous. (2019). Conducting forensic examination in the order of international legal assistance in criminal proceedings: Current issues of forensic examination and criminology: a collection of international materials. scientific-practical conference dedicated to the 150th anniversary of the birth of Zasl. prof. MS Bokarius (Kharkiv, April 18-19, 2019). Kharkiv: KhNDISE, 2019. 508 p. [in Ukr.]

\section{SUMMARY}

Yehor V. Sharai. Condition of scientific research involvement of employees of the expert service of the ministry of internal affairs of ukraine to the pre-trial investigation. The author analyzes some scientific studies carried out in the form of doctoral, candidate dissertations, monographs, a number of scientific articles, teaching materials, which gives grounds to conclude that the interaction of experts with investigators, operatives, defenders, their use of special knowledge in Many domestic and foreign scientists and practitioners are of interest to their activities, as well as the involvement of employees of the Expert Service of the Ministry of Internal Affairs of Ukraine in the pre-trial investigation in the context of modern adversarial criminal proceedings.

In addition, the author states that the versatility of the issue, the breadth of user interests in the development of scientific thought and scientific and technological progress, the importance of tasks performed by employees of the Expert Service of the Ministry of Internal Affairs indicate the urgency of this problem and provide grounds for further research.

Keywords: expert, Expert service of the Ministry of Internal Affairs of Ukraine, pre-trial investigation, interaction, involvement of employees, scientific research. 